\title{
IMPLEMENTASI TEKNOLOGI POMPA AIR TENAGA SURYA DI DESA KARYABARU KECAMATAN BARAMBAI KABUPATEN BARITO KUALA
}

\author{
Abdul Rozaq ${ }^{1}$, M. Firdaus Jauhari ${ }^{2}$, R. Kelik Hardinto ${ }^{3}$ \\ Politeknik Negeri Banjarmasin \\ rozaq@poliban.ac.id ${ }^{1}$ \\ firdaus.jauhari@poliban.ac.id $^{2}$ \\ rkelik@poliban.ac.id $^{3}$
}

\begin{abstract}
The research and community service program in the Pusat Penelitian dan Pengabdian Kepada Masyarakat (P3M) Politeknik Negeri Banjarmasin (Poliban) was prepared with reference to the application of science and technology that is able to provide appropriate solutions to problems, needs, and challenges in society. While community service activities focus on supporting efforts to improve community welfare and the competitiveness of universities.

Based on the 2016-2021 RPJMD vision, the South Kalimantan province's medium-term regional development mission is set for 2016-2021, one of which reads "Developing regional infrastructure that supports the acceleration of economic and social cultural development". Based on the mission, the province of South Kalimantan must provide a solution to the issue of uneven infrastructure development problems. One of the solutions that can be implemented relates to the availability of clean water in rural areas with the program "Infrastructure Development to Meet the Health of the Clean Water of Rural Communities". The problems that arise in the implementation of the program are limited equipment, technology and science, therefore Poliban in this case the P3M tries to provide a solution to the problems that exist in the village of Karyabaru, Barambai sub-district, Barito Kuala District which is very short of clean water. The solution is to make a solar water pump in the village of Karyabaru, Barambai sub-district, Barito Kuala Regency. The community service programs were carried out in partnership with the Karyabaru and Karang Taruna Village Devices /Karyabaru Village Farmers Group.

In order to guarantee the sustainability of the program that has been implemented later, it is then carried out assistance to the community so that all members of the community can participate in maintaining, caring for and implementing standards in the management of solar water pumps to meet clean water needs.
\end{abstract}

Keywords: water, pump, solar, cell

\begin{abstract}
ABSTRAK
Program penelitian dan pengabdian kepada masyarakat di Pusat Penelitian dan Pengabdian Kepada Masyarakat Politeknik Negeri Banjarmasin disusun dengan mengacu pada penerapan ilmu pengetahuan dan teknologi yang mampu memberikan solusi tepat guna terhadap permasalahan, kebutuhan, dan tantangan di masyarakat. Sedangkan kegiatan pengabdian kepada masyarakat berfokus pada upaya mendukung peningkatan kesejahteraan masyarakat dan daya saing perguruan tinggi.

Berdasarkan visi RPJMD tahun 2016-2021, maka ditetapkan misi pembangunan daerah jangka menengah provinsi Kalimantan Selatan tahun 2016-2021 yang salah satunya berbunyi "Mengembangkan infrastruktur wilayah yang mendukung percepatan
\end{abstract}


pengembangan ekonomi dan social budaya". Berdasarkan misi tersebut provinsi Kalimantan Selatan harus memberikan solusi atas isu permasalahan pembangunan infrastruktur yang belum merata. Adapun salah satu solusi yang dapat dilaksanakan berkaitan dengan ketersediaan air bersih di daerah pedesaan dengan program "Pembangunan Infrastruktur Guna Memenuhi Kebuhuhan Air Bersih Masyarakat Pedesaan". Adapun masalah yang muncul dalam pelaksanaan program tersebut adalah keterbatasan peralatan, teknologi dan ilmu pengetahuan, oleh karena itu Poliban dalam hal ini P3M mencoba memberikan solusi terhadap masalah yang ada di desa Karyabaru kecamatan Barambai Kabupaten Barito Kuala yang sangat kekurangan air bersih. Adapun solusinya adalah pembuatan pompa air tenaga surya di desa Karyabaru kecamatan Barambai Kabupaten Barito Kuala. Program-program pengabdian kepada masyarakat tersebut dilaksanakan melalui kemitraan dengan Perangkat Desa Karyabaru dan Karang taruna/Kelompok Tani Desa Karyabaru.

Dalam rangka menjamin keberlanjutan program yang telah dilaksanakan nantinya, maka selanjutnya dilakukan pendampingan kepada masyarakat agar semua anggota masyarakat dapat ikut menjaga, merawat dan menerapkan standar dalam kegiatan pengelolaan pompa air tenaga surya untuk memenuhi kebutuhan air bersih.

Kata Kunci: air, pompa, tenaga, surya

\section{PENDAHULUAN}

Air merupakan kebutuhan pokok manusia yang dapat diperoleh dari berbagai sumber tergantung dari daerah masing-masing. Sumber air di setiap daerah tentulah sangat berbeda yang dapat dilihat dari kondisi alam dan kegiatan warga di lingkungan tersebut. Warga yang berada di daerah rawa seperti di daerah Desa Karya Baru Kecamatan Barambai Kabupaten Barito Kuala Provinsi Kalimantan Selatan kesulitan memperoleh air bersih untuk keperluan rumah tangga. Air di daerah tersebut merupakan air gambut yang berdasarkan parameter baku mutu air tidak memenuhi syarat sebagai air bersih layak konsumsi (Kepmenkes No.492/MENKES/PER/IV/2010).

Ketersediaan air bersih yang memenuhi syarat untuk kebutuhan masyarakat tersebut sering menjadi masalah, terutama pada daerah yang sumber air permukaannya sangat terbatas dan banyak teknologi pompa untuk memperoleh air telah tersedia serta mudah diperoleh, akan tetapi pada daerah tertentu ketersediaan tenaga penggerak pompa sering menjadi kendala. Sebagai contoh ketiadaan jaringan listrik PLN atau tersedianya generator set (genset), tetapi sulit mendapat suplai BBM. Oleh karenanya untuk saat ini Teknologi Listrik Tenaga Surya (Solar Energi Sistem) dapat memberikan solusi untuk mengatasi hambatan tersebut. Cahaya matahari dapat diperoleh secara cuma-cuma sepanjang tahun, di mana saja, di tempat terpencil sekalipun untuk daerah tropis. Jadi pemanfaatan Teknologi Listrik Tenaga Surya untuk menggerakkan pompa air sangatlah tepat untuk memberikan solusi.

Politeknik Negeri Banjarmasin (Poliban) melaksanakan kegiatan berupa hilirisasi hasil penelitian multi disiplin yang dapat meningkatkan kemajuan desa baik di bidang sosial, ekonomi, hukum, kesehatan, budaya, pendidikan, pertanian, ketahanan pangan, maritim, energi baru dan terbarukan, dan lainnya, tanpa meninggalkan kekhasan yang telah dimiliki desa tersebut. Poliban sebagai perguruan tinggi dapat 
mempersiapkan tenaga kerja yang bisa bersaing secara nasional maupun internasional dilandasi oleh kepakaran di bidang Engineering, Bisnis, dan commerce dengan tetap menjaga keseimbangan lingkungan hidup, dan budaya berbasis kearifan lokal. RIP POLIBAN dan RENSTRA PENGABDIAN ditetapkan dengan harapan mampu menjawab berbagai tantangan dalam Rencana Pembangunan Jangka Panjang Nasional tahun 2030 yaitu mewujudkan masyarakat Indonesia yang mandiri, maju, adil, dan makmur melalui percepatan pembangunan di berbagai bidang dengan menekankan terbangunnya struktur perekonomian yang kokoh berlandaskan keunggulan kompetitif.

Kegiatan pengabdian diarahkan pada penemuan, pengembangan, dan pemanfaatan teknologi tepat guna untuk membantu meningkatkan kualitas hidup masyarakat melalui upaya hilirisasi kegiatan penelitian dan pemanfaatan hasil-hasil penelitian kepada masyarakat, terutama masyarakat pedesaan yaitu Desa Karya Baru Kecamatan Barambai Kabupaten Barito Kuala Provinsi Kalimantan Selatan yang berjarak $\pm 51 \mathrm{~km}$ dari Poliban yang berada di Banjarmasin sebagai ibu kota provinsi Kalimantan Selatan.

\section{METODE PELAKSANAAN}

\section{Metode Kegiatan}

\section{Tahap Sosialisasi}

Tahap sosialisasi diperlukan sebagai langkah awal pengenalan teknologi tenaga surya dengan aplikasi pompa air yang akan dipasang kepada masyarakat sehingga masyarakat tahu dan mengerti apa dan bagaimana cara memanfaatkan teknologi tersebut serta bagaimana cara merawat teknologi tersebut sehingga dapat dimanfaatkan dalam jangka waktu yang lama. Tahap sosialisasi ini dilakukan oleh tim diseminasi P3M Poliban. Selain untuk keperluan tersebut diatas, tahap ini juga berkaitan dengan persiapan lokasi juga perijinan lokasi yang akan digunakan sebagai tempat pemasangan alat.

\section{Tahap Penyediaan Peralatan}

Pada tahap ini dibagi menjadi 2 bagian yaitu pengadaan alat dan bagian pengadaan bahan.

Pengadaan alat yang merupakan satu kesatuan sistem meliputi pengadaan alat-alat berikut ini :

1. Satu unit. Pompa air yang digunakan dalam kegiatan ini adalah pompa air jenis pompa submersible (mampu ditenggelamkan),

2. Satu unit.controler Pompa air dc.Controller type ini tidak memiliki controller baterai sehingga jika menginginkan system yang dapat bekerja siang maupun malam dan membutuhkan baterai maka akan dibutuhkan controller baterai terpisah, dan baterai yang digunakan dengan voltase minimal 72 volt $(6 \times 12$ volt $)$. 
3. Sky Energy Monocrystalline Solar Modul STM 100 Watt peak (Wp) sebanyak 6 unit.Masing-masing solar modul dapat menghasilkan voltase sebesar 12 volt, oleh karena yang digunakan adalah pompa Lorentz type HR-14 dengan controller pompa PS1200 dimana kedua alat ini membutuhkan daya dengan voltase minimum 72 volt, maka dibutuhkan solar modul sebanyak 6 buah.

Pengadaan bahan yang merupakan pendukung dari sistem yang dibuat meliputi :

1. Pengadaan tiang support modul surya. Tiang support modul surya ini terdiri dari sebuah tiang dengan diameter 6 inch dan besi siku $5 \times 5 \mathrm{~cm}$ serta besi siku $4 \times 4 \mathrm{~cm}$.

2. Pengadaan box panel untuk menyimpan controller.

3. Pengadaan kabel-kabel yang dibutuhkan.

4. Pengadaan bak pengumpul air dibantaran aliran tersier.

5. Pengadaan tutup bak pengumpul air, yang berfungsi sebagai pengaman pompa air yang ditempatkan didalam bak tersebut.

6. Pengadaan tandon air. Berhubung diwilayah pemasangan merupakan wilayah dengan air payau dan cenderung asin, maka digunakan tandon air yang terbuat dari plastik karena jika menggunakan tandon air dari besi/stainless stell dikawatirkan akan mudah berkarat dan rusak.

7. Pembuatan landasan tandon air, landasan ini berbentuk prisma berukuran diameter atas 2 meter, diameter bawah $\pm 2,5$ meter, dengan ketinggian 1,5 meter.

8. Pengadaan pipa dari pompa menuju tandon air.

\section{Tahap Instalasi}

Pada saat tahap pengadaan dilaksanakan disiapkan pula untuk tahap selanjutnya yaitu tahap instalasi. Dalam tahap instalasi ada beberapa kegiatan yaitu:

1. Pemasangan Support Modul Surya. Tiang support modul surya dipasang sejajar dengan arah kemiringan menghadap ke utara, hal ini dilakukan karena lokasi pemasangan berada diselatan khatulistiwa sehingga matahari akan lebih sering berada disebelah utara, oleh karena itu agar modul surya bisa lebih banyak menerima cahaya matahari sepanjang tahun.

2. Pemasangan Box Panel. Box panel dipasang pada tiang support pada ketinggian $>2$ meter, hal ini dimaksudkan agar box panel ini jauh dari jangkauan hewan dan juga dari tangantangan jahil.

3. Pemasangan Modul Surya. Modul surya dipasang dalam 2 baris 3 kolom. Antar modul disambung menggunakan kabel sehingga tercapai voltase 72 volt. Modul surya dipasang miring dengan kemiringan sebesar $10-15^{\circ}$ dari posisi tegak tiang support modul surya, hal ini berfungsi untuk memudahkan debu dan benda lainnya yang jatuh kepermukaan modul surya akan lebih mudah jatuh sehingga tidak akan mengotori modul surya yang nantinya dapat menurunkan kinerja modul surya tersebut. 
4. Pemasangan controller pompa. Controller pompa dipasang didalam box panel, diharapkan akan aman dari pencurian.

5. Pemasangan pompa. Pompa air dipasang didasar bak penampungan air, dengan diberi casing dari pipa yang lebih besar dari pompa sehingga pompa tidak langsung bersentuhan tanah didasar bak. Selain itu dibadan pompa diberi pelampung ketinggian air, sehingga jika ketinggian minimum air tidak tercapai maka otomatis sistem akan mati dan pompa tidak terus bekerja tanpa ada air yang dipompa.

6. Instalasi perpipaan ke tandon air. Pipa dipasang langsung dari pompa menuju tandon air.

Dengan kegiatan pengadaan instalasi pompa air tenaga surya ini, masyarakat pedesaan terutama masyarakat Desa Karya baru, Kecamatan Barambai, Kabupaten Barito Kuala, telah mengenal teknologi yang dapat dikembangkan lebih lanjut diwilayahnya, yang diharapkan pula dapat tersebar informasi tentang teknologi ini kewilayah lainnya disekitar lokasi pemasangan. Selain itu dengan kegiatan ini telah turut mendukung komitmen Pemerintah yang berkeinginan untuk menurunkan emisi gas karbon sampai $26 \%$ pada tahun 2020 .

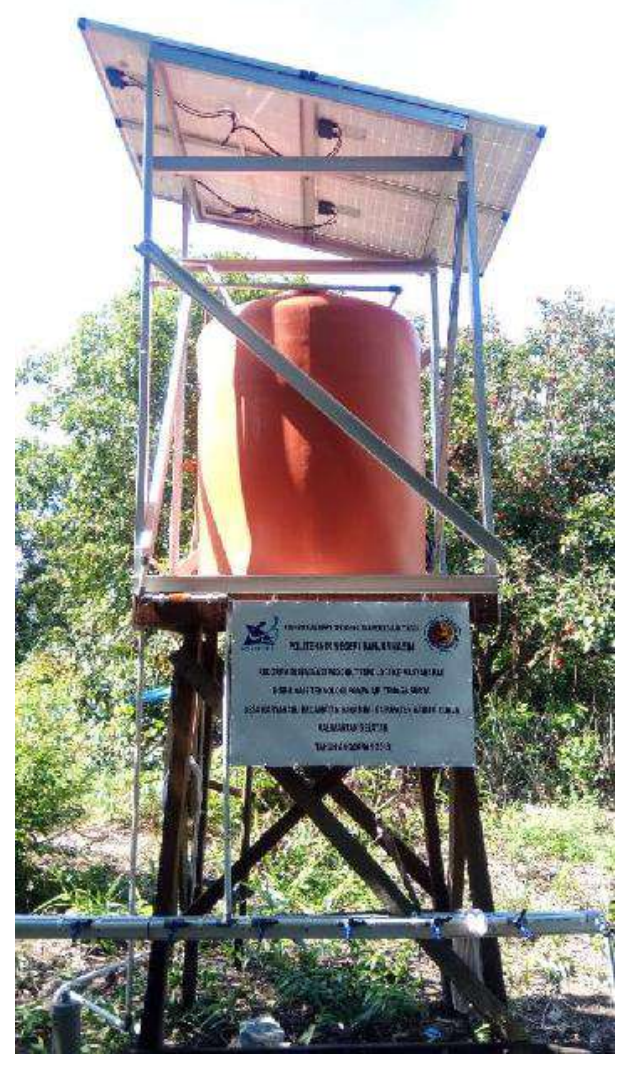

Gambar 1. Intalasi Pompa air tenaga surya 


\section{Deskripsi Teknologi yang akan di desiminasikan ke masyarakat}

Tahapan proses pengolahan terdiri dari beberapa tahap yaitu:

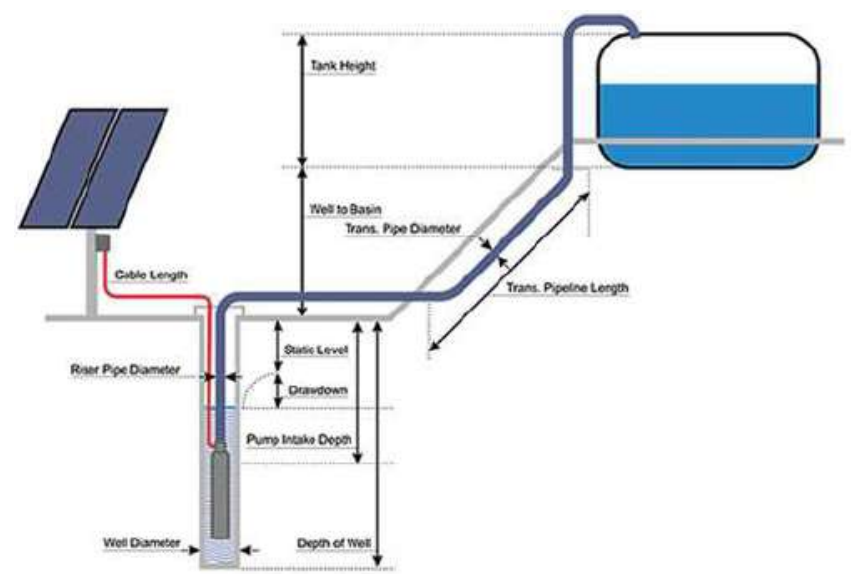

Gambar 2. Skema pompa air tenaga surya

Pada gambar di atas, dapat dilihat skema Pompa Air Tenaga Surya. Dimana pompa mendapat pasokan energi langsung dari panel surya untuk memompa air hingga ketinggian (Head) dan jarak yang diperlukan.

Pada waktu pagi hingga sore hari dimana intensitas cahaya matahari cukup, secara otomatis pompa akan bekerja. Setelah sore hari saat cahaya matahari terus berkurang hingga berhenti (malam hari), pompa otomatis akan berhenti bekerja. Demikian seterusnya setiap pagi hingga sore pompa akan bekerja rata-rata 8 jam per hari untuk mengisi reservoir sesuai dengan kapasitas yang diperlukan. Tidak direkomendasikan untuk menyimpan energi listrik dalam battery (akumulator), tetapi direkomendasikan menyimpan air dalam tangki penampung / tandon air (reservoir).

Untuk membangun Sistem Pompa Air Tenaga Surya dengan desain dan anggaran yang tepat, diperlukan survey lokasi yang intensif guna mengukur jarak dan ketinggian (head) mulai dari sumber air, tangki penampung (reservoir), hingga daerah pelayanan serta kapasitas yang dibutuhkan untuk mensuplai area pelayanan (masyarakat pengguna).

Survey ini sangat diperlukan agar tidak terjadi kesalahan dalam perhitungan desain yang sangat berpengaruh terhadap nilai investasi yang diperlukan.

Secara garis besar, hal-hal yang harus diperhatikan dalam membangun suatu sistem pengadaan air yang menggunakan teknologi ini adalah sebagai berikut :

- Sumber air, dapat berupa sumur bor, sumur dangkal, atau mata air. Apabila sumber air tersebut harus melalui proses pengolahan/treatment, maka instalasi pengolahan harus dihitung nilainya.

- Instalasi Pompa Air Tenaga Surya, terdiri dari : panel surya, pompa, dan panel kontrol 
- Tangki penampung utama (reservoir), berupa tangki Fiberglass atau PE dengan kapasitas besar yang ditempatkan pada ketinggian tertentu, sehingga dapat mengalir ke wilayah/area pelayanan dengan sistem gravitasi.

- Jaringan Distribusi, adalah jaringan pipa (PVC/HDPE/Steel) guna menyalurkan air dari tangki penampung ke area pelayanan/rumah penduduk

- Area Pelayanan, dapat berupa tangki penampung dengan kapasitas lebih kecil dari tangki penampung utama atau dapat juga langsung disalurkan ke rumah-rumah dengan dilengkapi water meter (seperti halnya sistem pelayanan PDAM).

\section{HASIL DAN PEMBAHASAN}

\section{Rembuk Desa}

Pelaksanaan Diseminasi Teknologi Pompa Air Tenaga Surya Di Desa Karyabaru Kecamatan Barambai Kabupaten Barito Kuala dilaksanakan diawali koordinasi dengan perangkat Desa dalam bentuk rembuk desa. Dalam rembuk desa dibahas tentang kegiatan yang akan dilaksanakan berupa Diseminasi Teknologi Pompa Air Tenaga Surya yang bertujuan untuk memenuhi kebutuhan air bersih masyarakat di desa karyabaru. Dalam rangka dapat terlaksananya kegiatan tersebut, maka perlu ditentukan lokasi dalam pengeboran. Sedangkan untuk menentukan lokasi pengeboran diperlukan kesepakatan antara warga masyarakat, sehingga Teknologi Pompa Air Tenaga Surya Di Desa Karyabaru dapat dinikmati oleh seluruh warga masyarakat yang memerlukan air bersih yang layak konsumsi. Adapun dari rembuk desa disepakati bahwa lokasi pengeboran bertempat di perkebunan masyarakat yang dapat diakses oleh setiap warga masyarakat di Desa Karyabaru untuk dapat memanfaatkan secara Bersama Teknologi Pompa Air Tenaga Surya yang diterapkan.

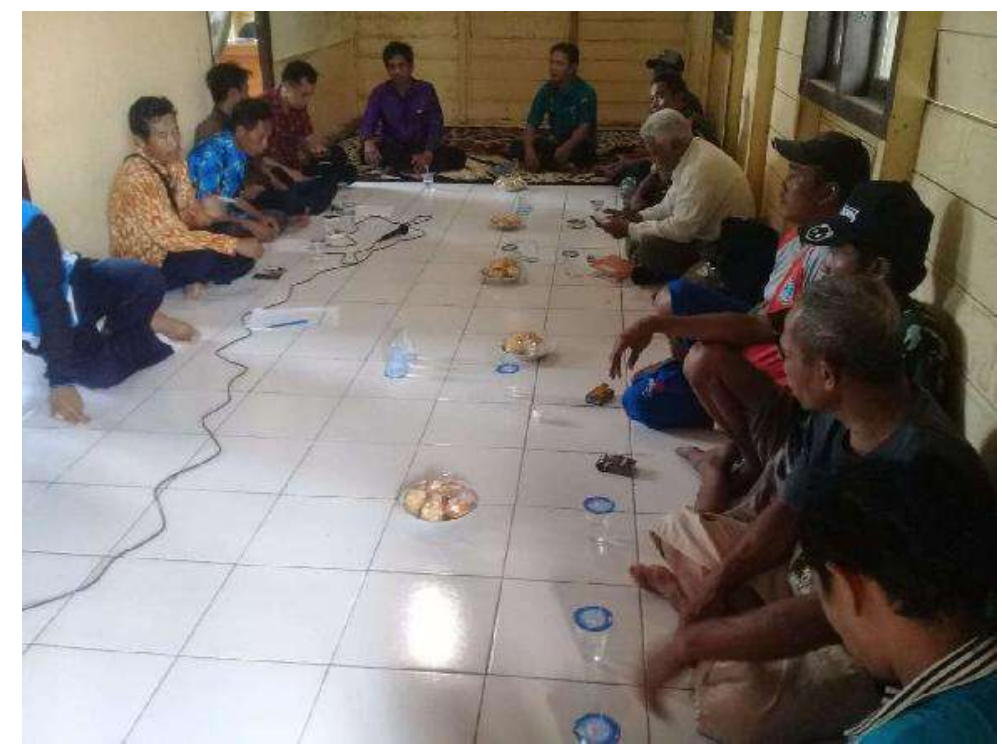

Gambar 3. Rembuk desa 


\section{Survei Lokasi Pengeboran}

Setelah dilaksanakan rembuk desa dengan kesepakatan penetapan lokasi pengeboran, maka langkah selanjutnya adalah melakukan survei lokasi pengeboran. Tujuan dari survei adalah menentukan titik pengeboran secara cermat dan tepat, sehingga dapat ditemukan sumber air tanah yang baik.

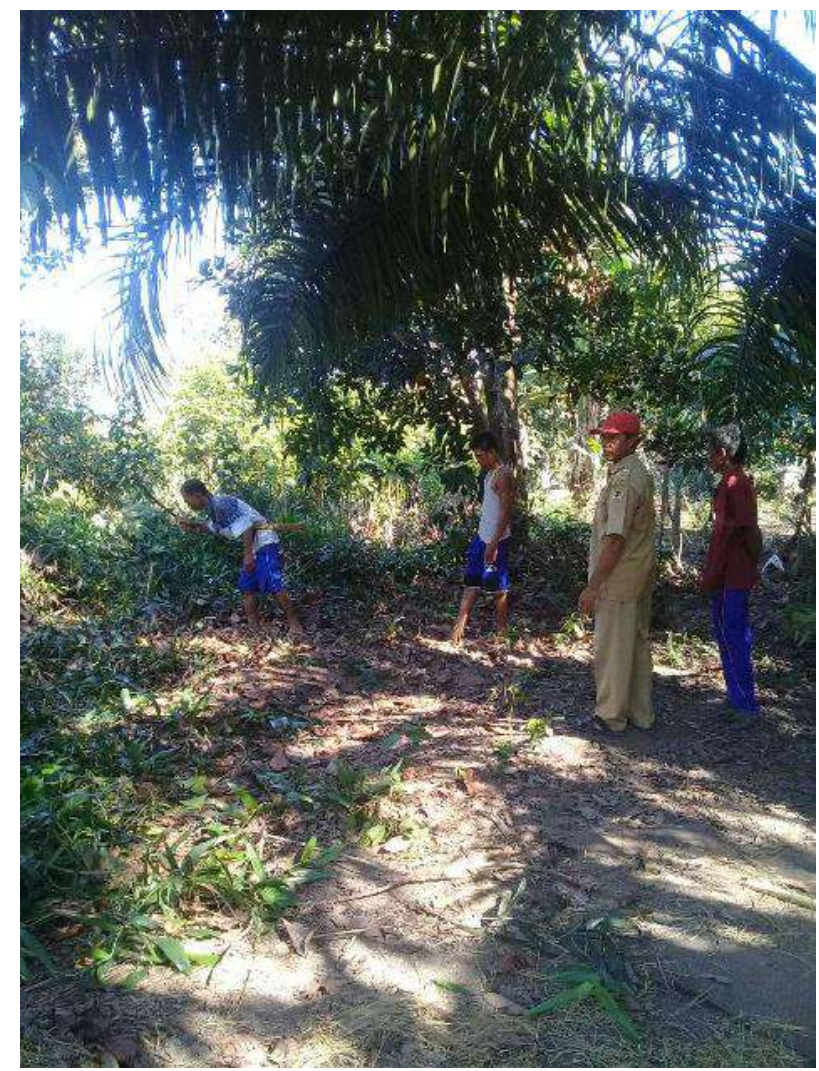

Gambar 4. Survei lokasi pengeboran Bersama warga

Gambar 4. adalah kegiatan survei lokasi pengeboran yang telah disepakati dari hasil rembuk desa. Survei lokasi ini dilaksanakan oleh tim Diseminasi Bersama perangkat desa Karyabaru dan warga masyarakat sekitar. Lakosi yang dicari dalam survei adalah lokasi pengeboran yang dapat diakses oleh semua warga masyarakat yang membutuhkan air bersih dan terkait teknologi tenaga surya, maka lokasi pengeboran tersebut harus ruang terbuka sehingga sinar matahari dapat diperoleh dengan sempurna.

\section{a. Proses pengeboran}

Sumur bor merupakan pilihan yang cukup populer sekarang ini, bahkan menjadi kebutuhan bagi masyarakat yang akan membuat sumur. Sumur sebagai fasilitas dimana kita mengambil air bersih dari perut bumi merupakan kebutuhan primer bagi setiap masyarakat terlebih pada saat musim kemarau.

Pilihan membuat sumur dengan cara dibor menggunakan alat bantu manusia sebagai penggeraknya yang biasa disebut Sumur Bor Manual atau menggunakan 
mesin sebagai penggerak mata bornya disebut Sumur Bor Mesin. Dalam proyek ini system yang dipakai untuk membuat sumur bor dengan menggunakan mesin sebagai penggerak mata bornya yang lazim disebut sumur bor mesin.

Tahapan pembuatan semur bor sebagai berikut :

1. Proses persiapan peralatan yang digunakan untuk pembuatan sumur bor :

$\checkmark \quad$ Pipa besi berulir

$\checkmark \quad$ Kunci pipa

$\checkmark \quad$ Mesin bor pipa

$\checkmark \quad$ Pompa penyedot air

$\checkmark \quad$ Cangkul/alat penggali

$\checkmark \quad$ Rangka penyangga pipa bor

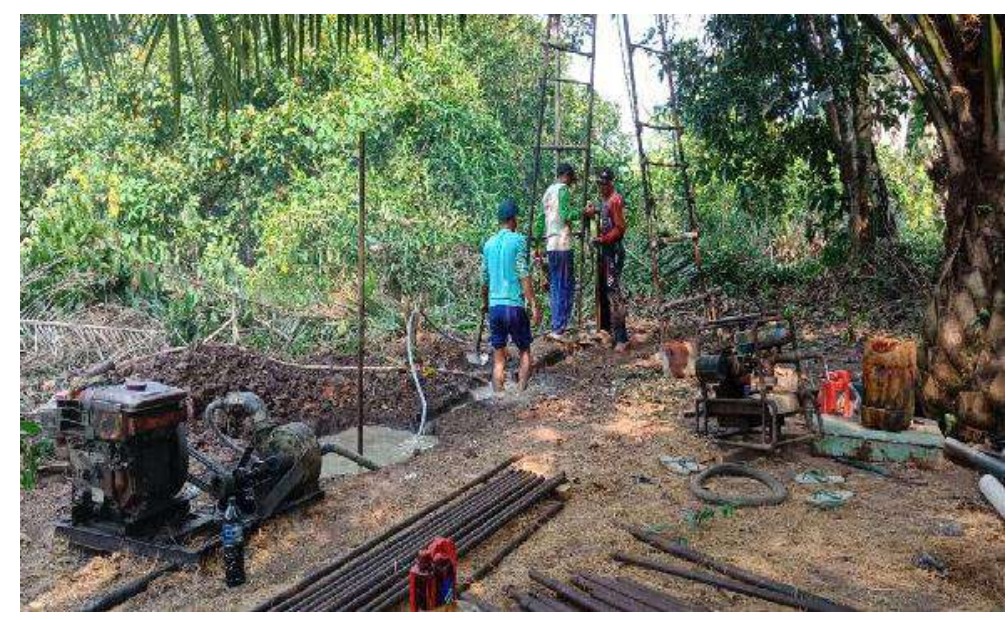

Gambar 5. Persiapan peralatan pengeboran

a) Penentuan titik awal lokasi mata bor yang akan ditancapkan,dengan harapkan terdapat sumber mata air tanah.
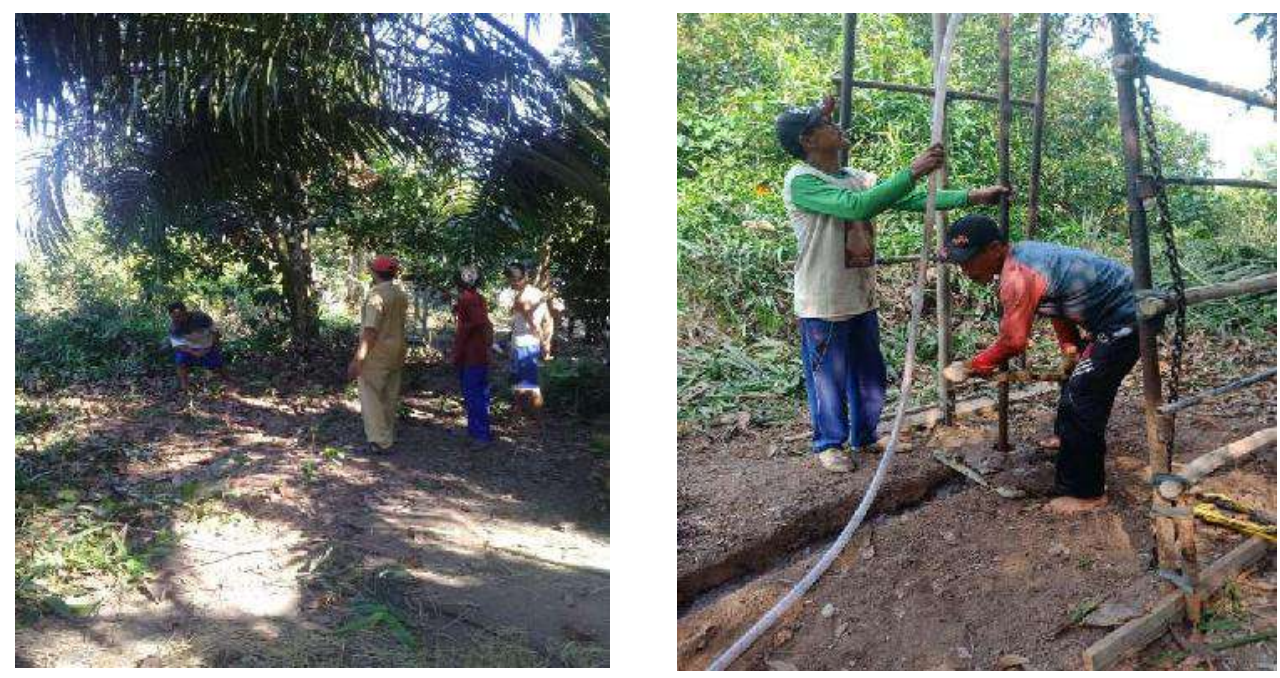

Gambar 6. Titik awal lokasi penancapan mata bor 
b) Cari tempat yang akan dijadikan sumur, lalu cangkul permukaannya sampai sekira $60 \mathrm{~cm}$. Lalu isi air agar memudahkan pemasangan pipa bor

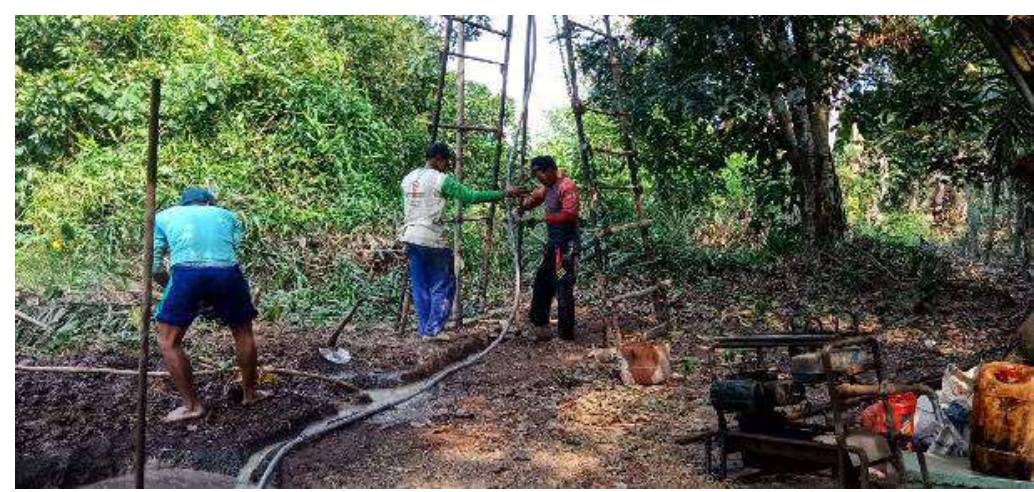

Gambar 7. Persiapan pengeboran

Pada gambar 7. merupakan persiapan tim untuk melakukan pengeboran dengan peralatan yang sudah disiapkan. Adapun titik pengeboran yang telah ditentukan disiapkan sedemikian rupa sehingga akan memudahkan proses pengeboran tanah dengan kedalaman sampai dengan mendapatkan air tanah yang baik dan layak untuk dikonsumsi.

c) Pasang mesin penyedot air; satu lubangnya dipasang selang untuk menyedot, satu lubangnya lagi dipasang ke pipa besi/pipa bor untuk mengairi tanah supaya lebih gampang dibor.

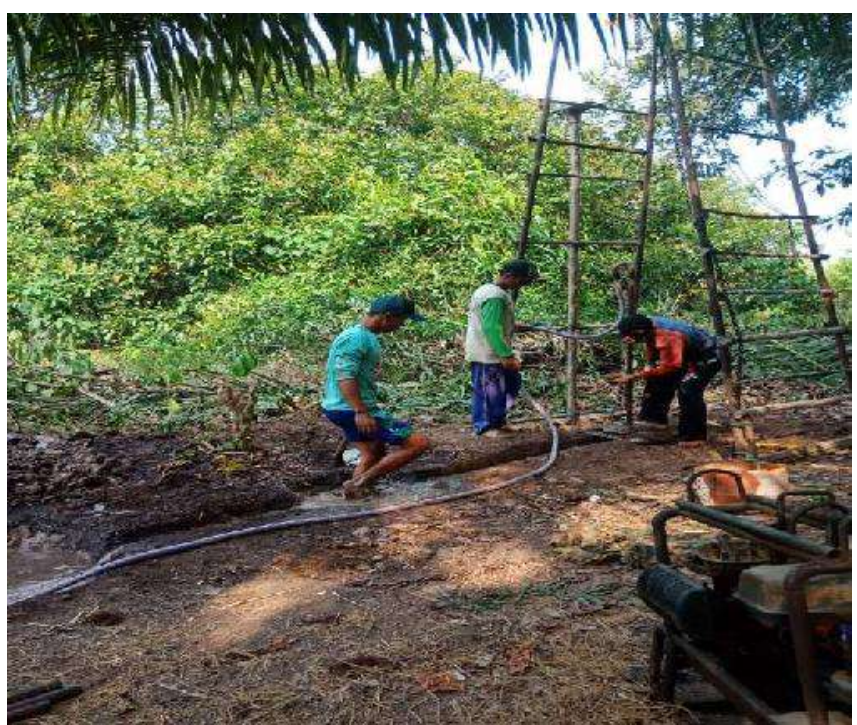

Gambar 8. Proses pengeboran

d) Benamkan pipa bor ke dalam tanah

e) Capit batang pipa bor dengan kunci pipa, lalu putar satu arah kemudian hubungkan pipa ke mesin putar bor 

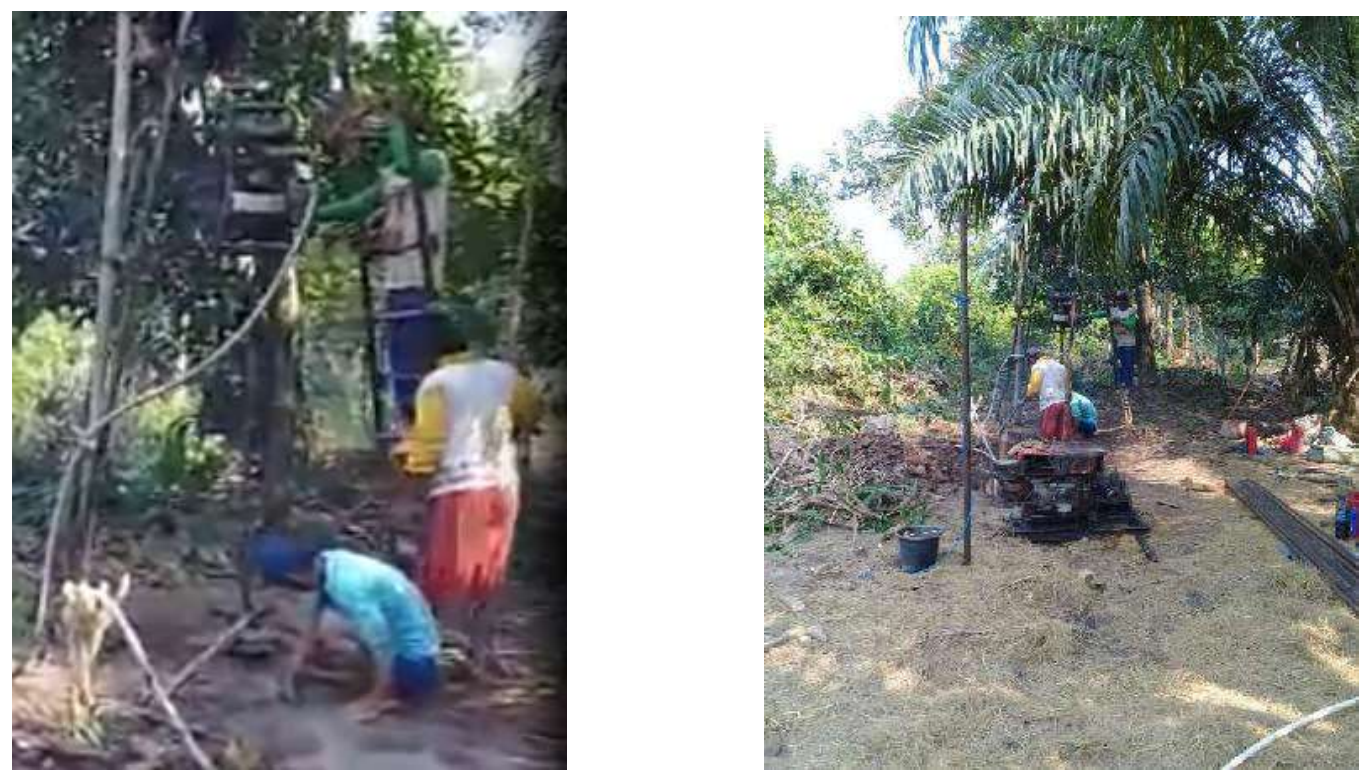

Gambar 9. Tahapan proses pengeboran

f) Satu persatu pipa besi berulir dimasukkan ke dalam tanah dimana pipa berputar ke dalam tanah untuk mencapai titik terbaik dari sumber air tanah.
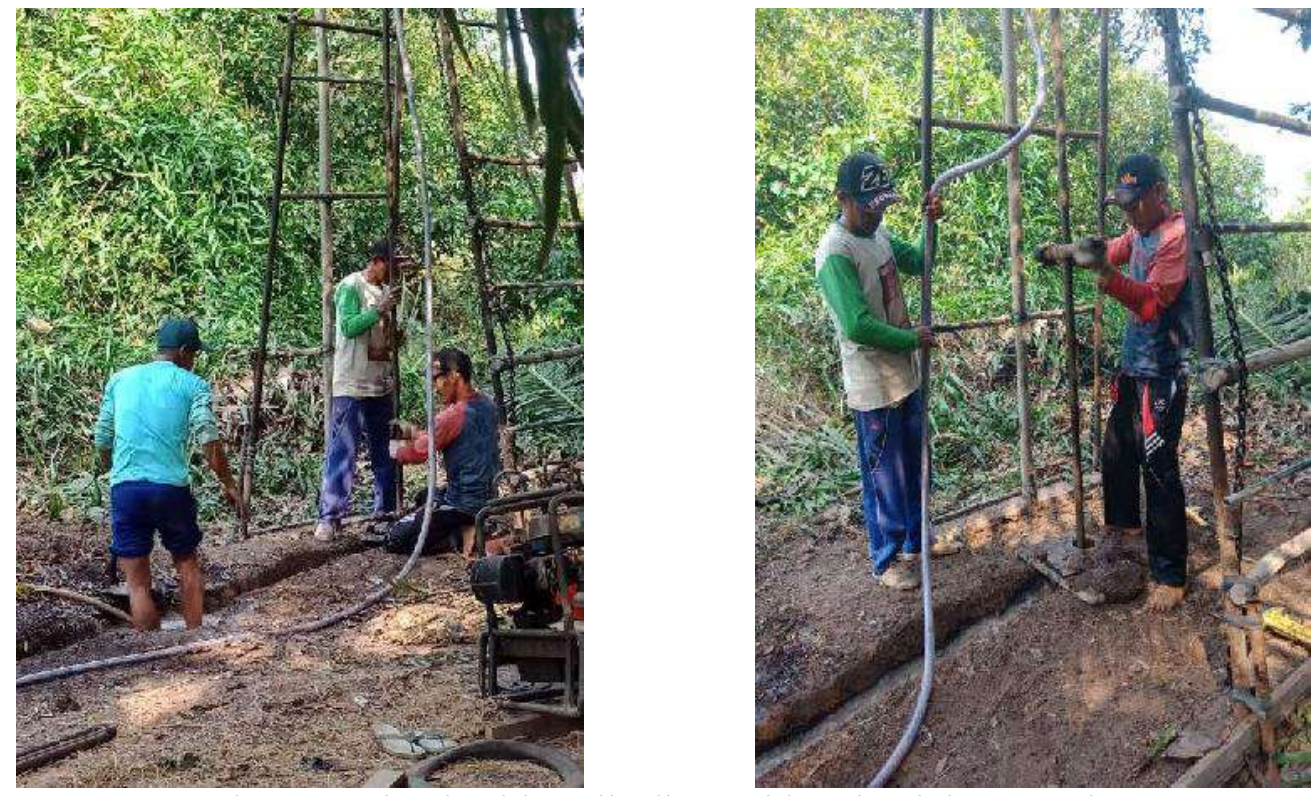

Gambar 10. Pipa besi berulir dimasukkan ke dalam tanah

g) Setelah merasa cukup dalam dan sesuai dengan kedalaman yang diinginkan dimana dalam proyek ini kedalam yang dicapai +/- $100 \sim 120$ meter, selanjutnya pasang pipa secara berurutan dari yang paling besar sampai yang terkecil; gunanya untuk menopang tanah agar tidak ambruk. 


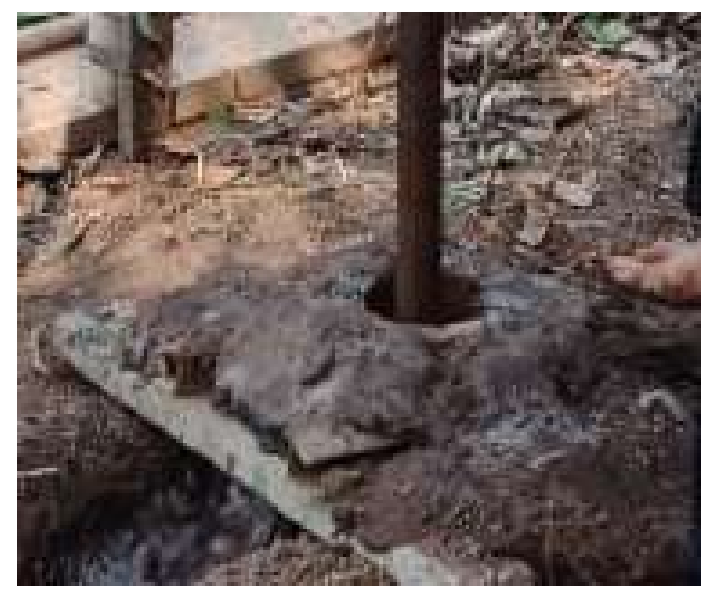

Gambar 11. Pemasangan pipa sebagai penopang tanah

h) Setelah proses pengeboran selesai, maka selanjutnya adalah menguras air hasil dari pengobaran yang ada sampai mendapatkan air bersih.

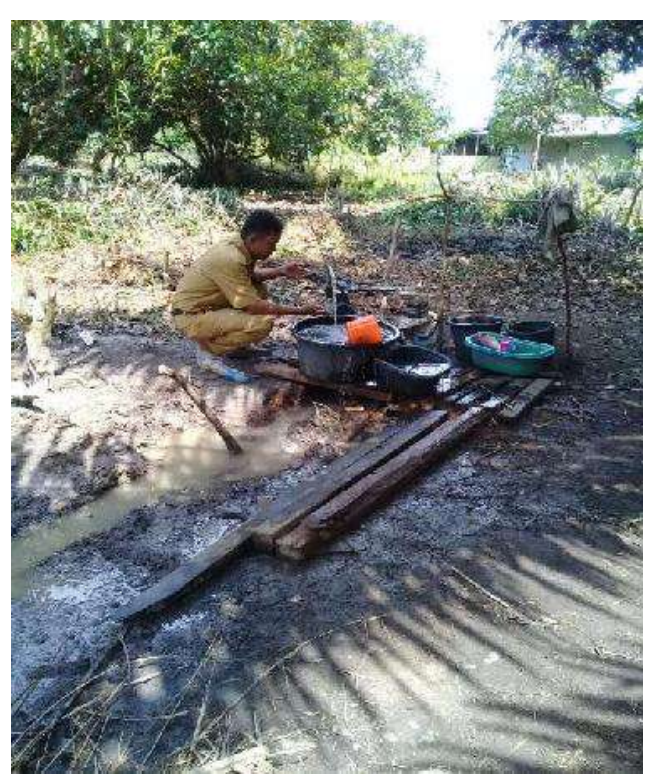

Gambar 12. Pengecekan kualitas air oleh perangkat desa

Gambar 12. adalah pengecekan kualitas air hasil dari pengeboran dengan kedalaman 100-120 m. Pengecekan kualitas air ini dilakukan oleh perangkat desa dengan tujuan bahwa air yang di dapatkan dari hasil pengeboran adalah air tanah yang baik dan layak konsumsi. Dari hasil pengecekan oleh perangkat desa, maka disimpulkan bahwa air tanah yang dihasilkan dari pengeboran adalah air tanah yang baik dan layak konsumsi.

Setelah dipastikan bahwa air tanah yang baik dan layak konsumsi telah di dapat, maka selanjutnya tim akan melakukan uji coba mesin pompa air tenaga surya. 


\section{b. Uji Coba Mesin Pompa Air Tenaga Surya}

Pemanfaatan air tanah dengan media sumur bor yang diangkat dengan menggunakan pompa yang digerakkan oleh energi listrik maupun generator, akan memerlukan biaya operasional (listrik atau bahan bakar) yang tinggi sehingga keberlanjutan (sustainability) usaha pompa dalam pendayagunaan air tanah tidak dapat dipertahankan.

Teknologi pemanfaatan energi sinar matahari, sedikit banyak dapat mengantisipasi kendala tersebut. Kita mengetahui bahwa di wilayah tropis, sinar matahari sangat melimpah sepanjang tahun. Seperti namanya, teknologi ini sepenuhnya memanfaatkan energi sinar matahari yang melimpah dan gratis sepanjang tahun.Selain tidak memerlukan energi listrik dari PLN atau genset, teknologi Pompa Air Tenaga Surya ini minim perawatan dan bekerja secara otomatis.

Bahan bahan yang di gunakan untuk instalasi pompa air tenaga surya adalah :

1. Panel Surya

Dalam proyek ini panel surya yang di pakai dengan kapasitas $=250 \mathrm{Wp}$ sebanyak 4 buah

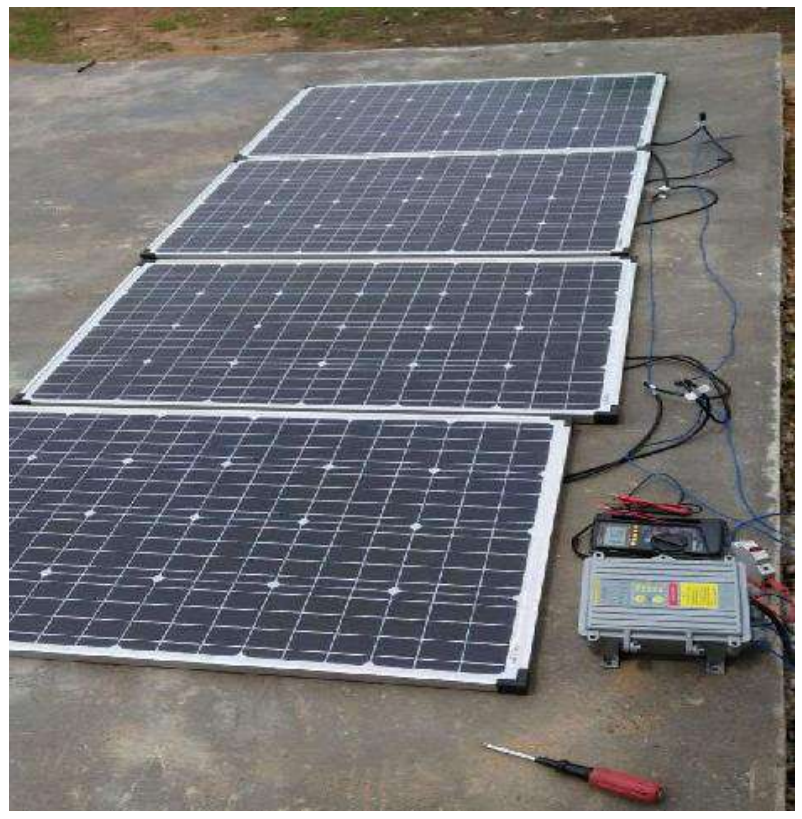

Gambar 13. Panel tenaga surya

2. Pompa

Pompa yang digunakan pada proyek ini adalah tipe submersible tenaga surya sebanyak 1 unit diameter 3 “ 


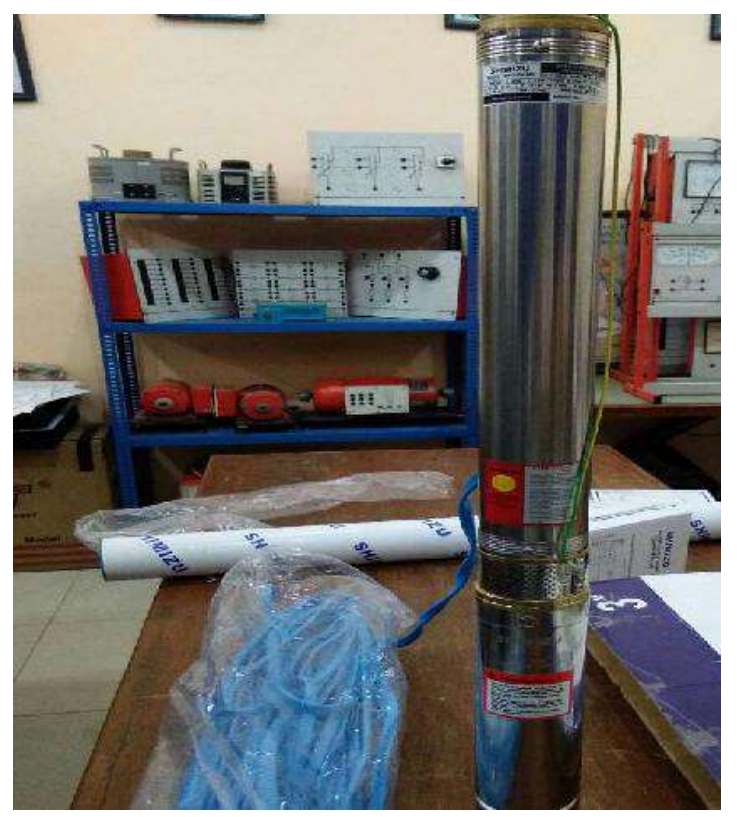

Gambar 14. Mesin pompa tenaga surya

3. Panel Kontrol
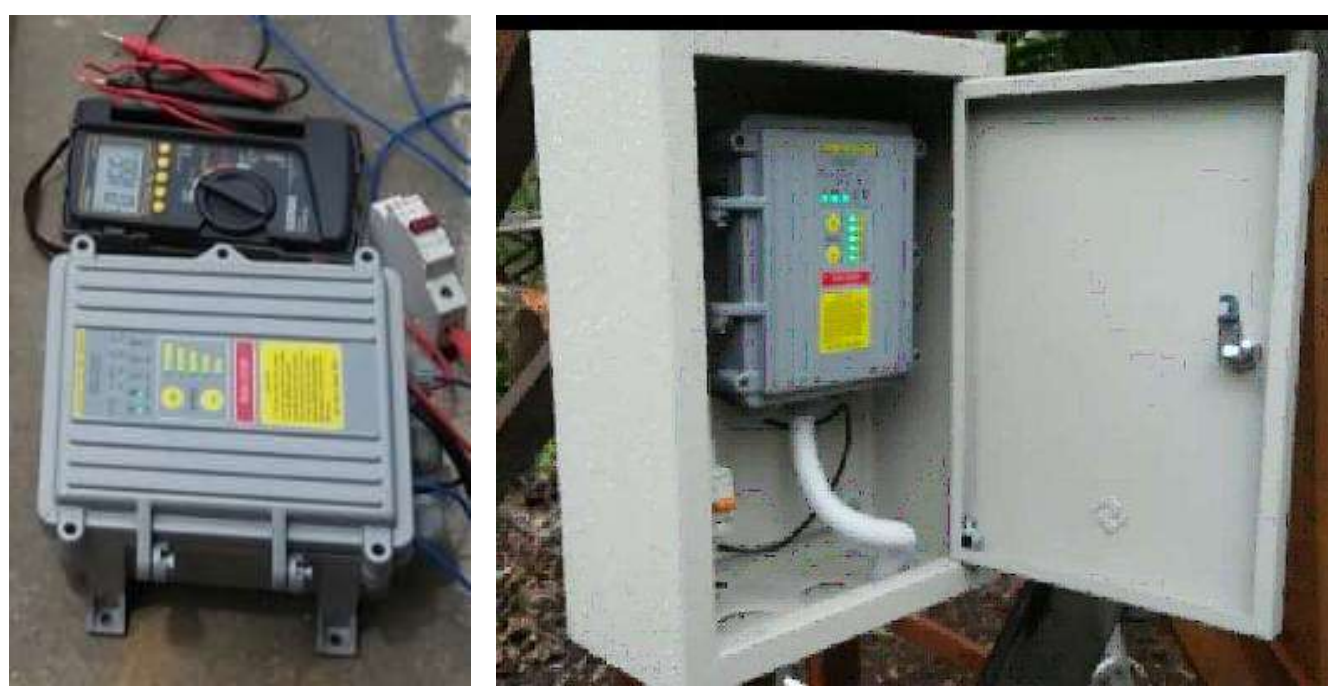

Gambar 15. Panel Control tenaga surya

Langkah kerja Insatalasi pompa air tenaga surya

1. Penyiapan bahan dan peralatan kerja

2. Uji coba keadalan system cell surya apakah bekerja dengan baik,yang meliputi ;

Panel surya, control panel dan pompa 


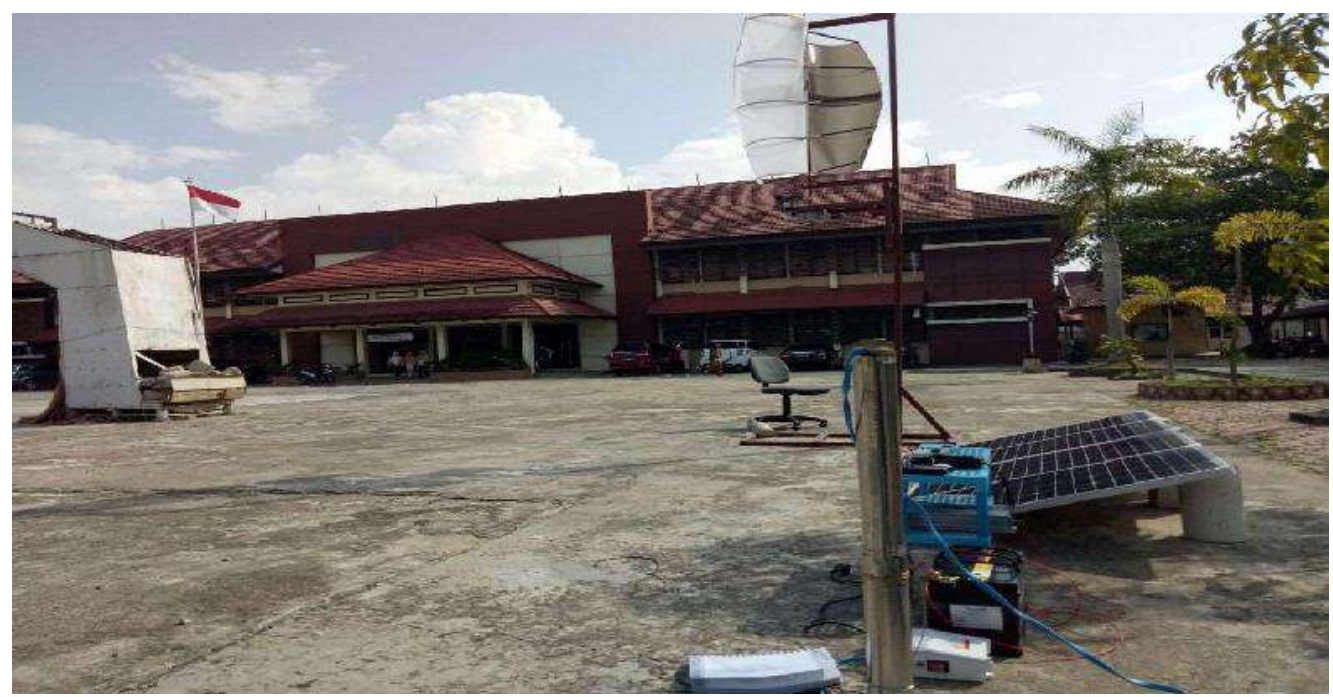

Gambar 16. uji coba full set pompa air tenaga surya
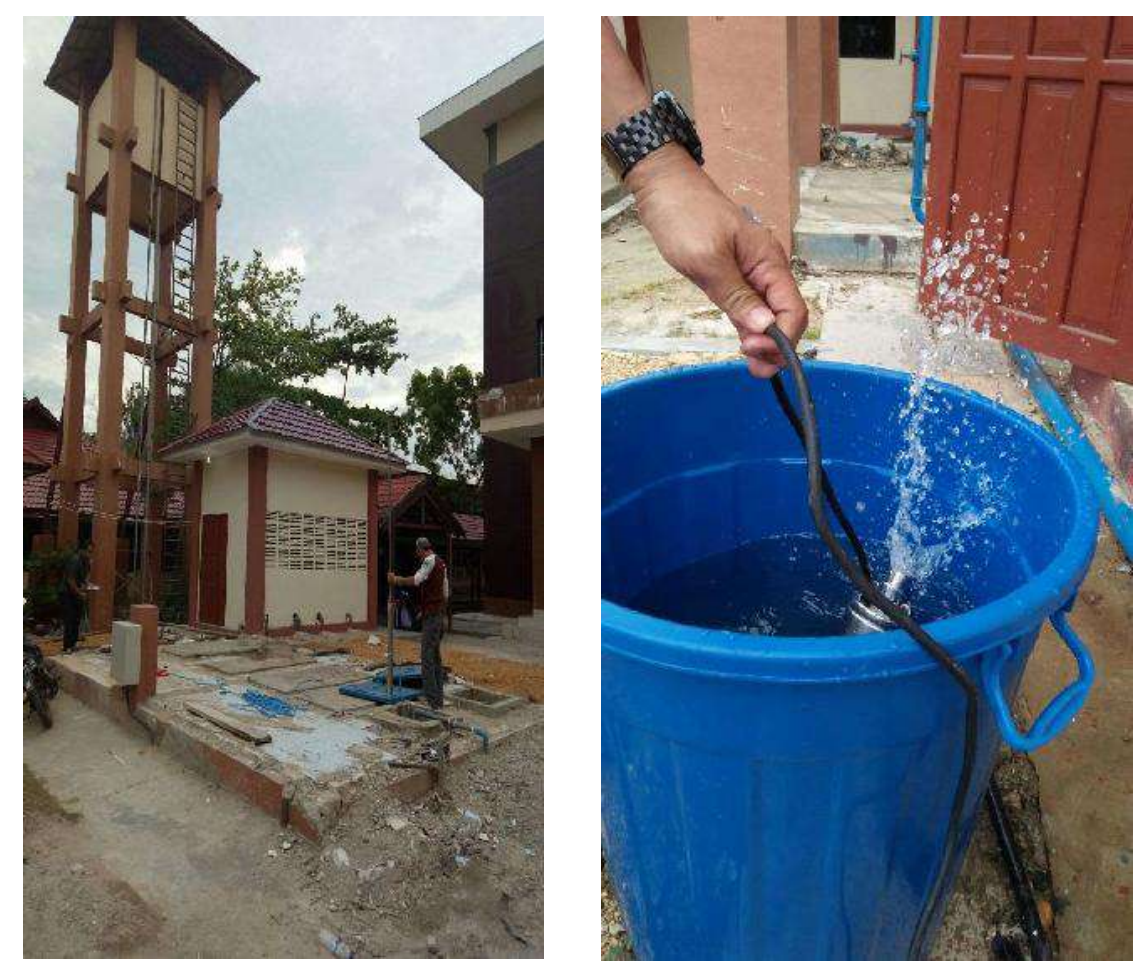

Gambar 17. Pompa air tenaga surya berjalan dengan baik

\section{c. Instalasi Mesin Pompa Air Tenaga Surya}

Pada tahap instalasi pompa air tenaga surya dilaksanakan oleh tim dan dibantu oleh warga masyarakat, sehingga proses instalasi dapat berjalan dengan lancer. Adapun tahapan instalasi dapat dilihat pada foto-foto di bawah ini : 

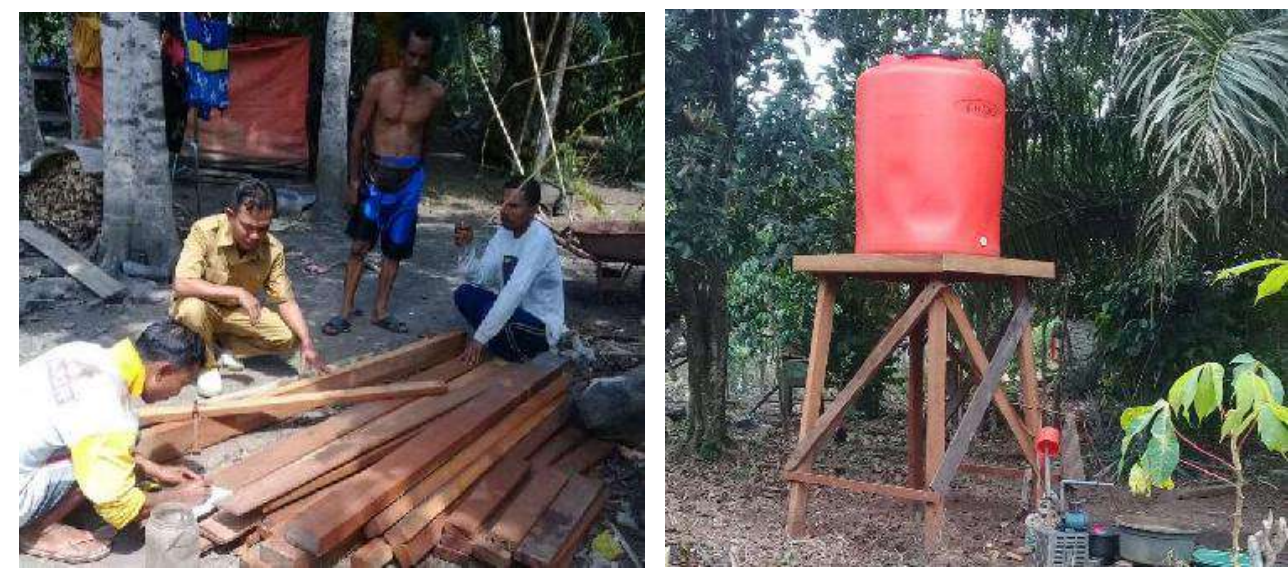

Gambar 18. Proses instalasi rangka penyangga tandon

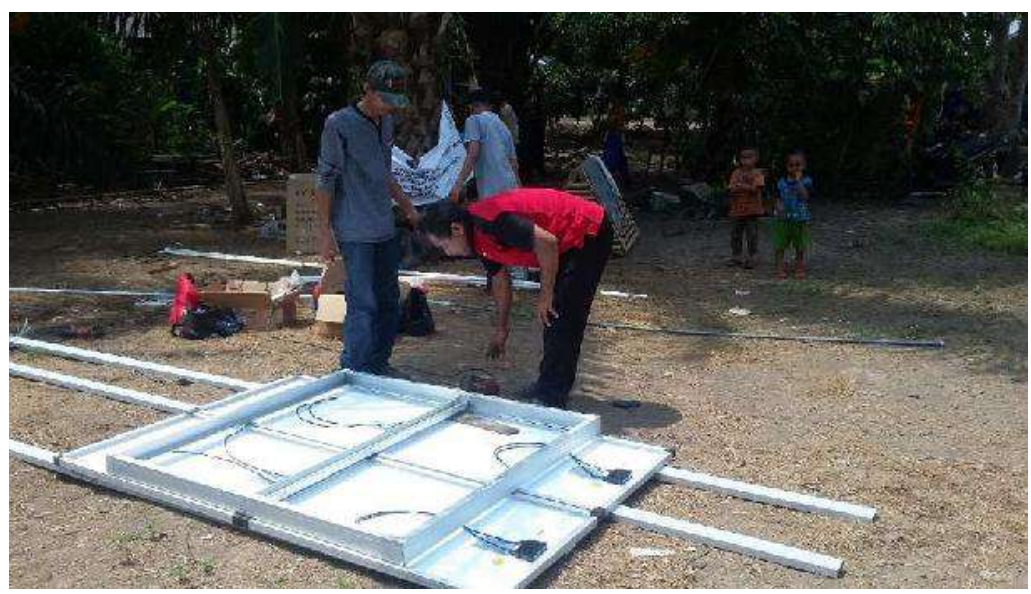

Gambar 19. Instalasi panel tenaga surya

Pada tahap ini tim menyiap proses instalasi panel-panel tenaga surya yang akan digunakan sebagai sumber daya listrik pompa air.

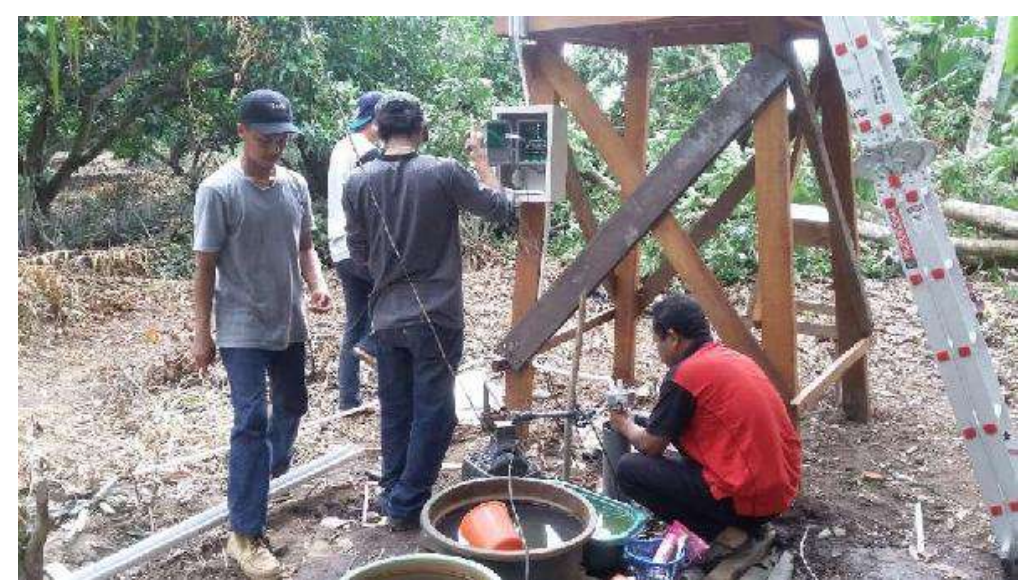

Gambar 20. Cek input kelistrik dari panel tenaga surya yang sudah terpasang 
Tim melakukan pengecekan daya listrik yang bisa tersalurkan dari panel-panel surya menuju pompa air. Untuk mengatur aliran daya listrik, diperlukan control sehingga arus listrik dapat mengalir dengan stabil.

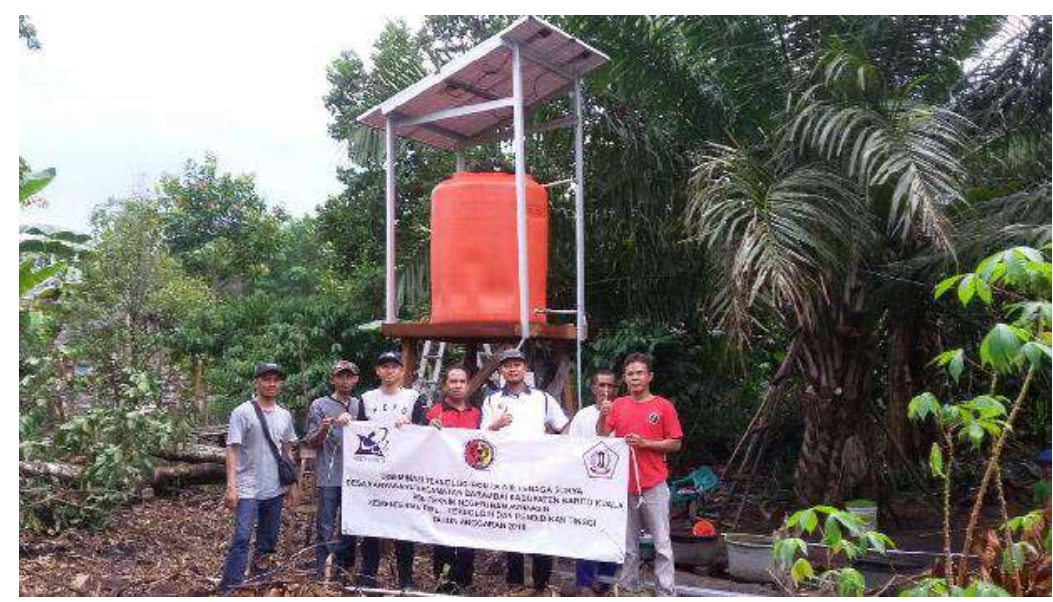

Gambar 21. Instalasi sudah selesai dilaksankan
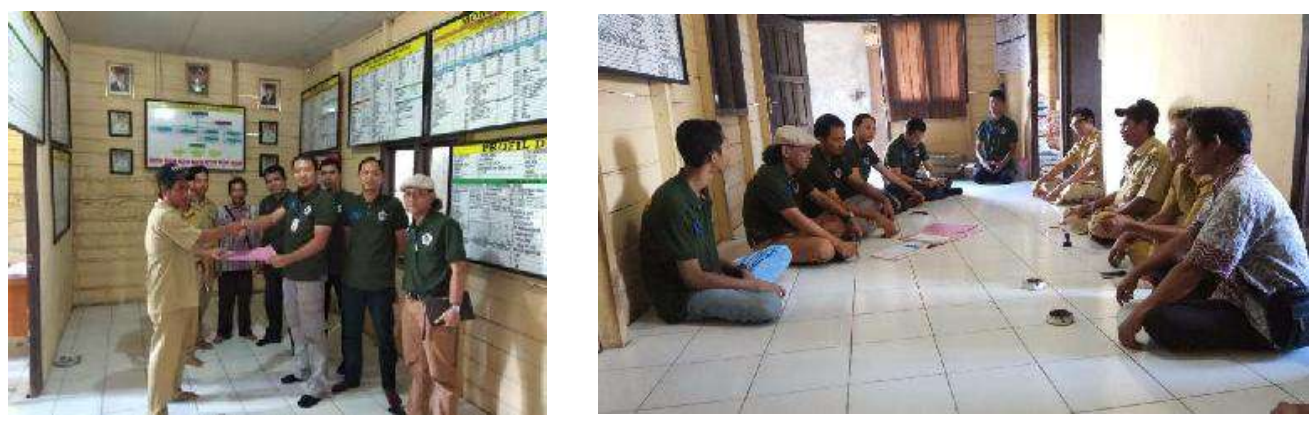

Gambar 22. Serah terima dan diskusi teknologi pompa air tenaga surya

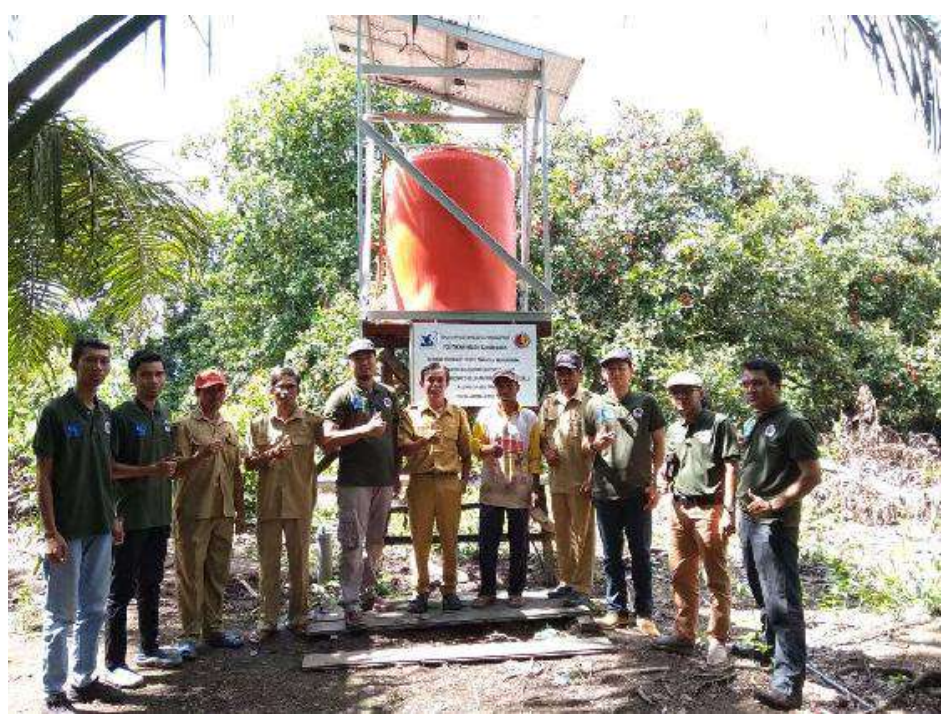

Gambar 23. Pompa air tenaga surya dimanfaatkan oleh masyarakat 


\section{KESIMPULAN}

Kegiatan Diseminasi Pompa Air Tenaga Surya di Desa Karyabaru kecamatan Barambai Kabupaten Barito Kuala diterima dengan baik oleh masyarakat, sehingga rangkaian kegiatan dapat berjalan dengan lancar. Masyarakat sangat terbantu dalam memenuhi kebutuhan air layak konsumsi dengan diterapkannya teknologi pompa air tenaga surya

\section{Harapan Masyarakat}

Masih perlu diimplementasikannya teknologi Pompa Air Tenaga Surya di Desa Karyabaru terutama di titik titik kordinat lain yang masyarakatnya masih sangat membutuhkan air bersih, minimal 3 titik lagi yang diinginkan oleh masyarakat. Di desa Karyabaru juga sangat memerlukan penerangan jalan dengan menggunakan tenaga surya, karena sampai saat ini penerangan jalan belum ada meskipun perangkat desa sudah mengajukan permohonan kepada PLN

\section{UCAPAN TERIMA KASIH}

Terimakasih kepada Kemenristekdikti yang telah mendanai kegiatan Diseminasi Pompa Air Tenaga Surya di Desa Karyabaru Kecamatan Barambai Kabupaten Barito Kuala

\section{DAFTAR PUSTAKA}

Arrohman Roni Eka, Setiawan Ahmad Agus, dan Sihana. (2012). Perancangan Sistem Pengangkatan Air Tenaga Surya di Kecamatan Tepus Kabupaten Gunungkidul. Jurnal TEKNOFISIKA. Vol 1 No.1: 134.

Departemen Pendidikan Nasional. (2006). Pengenalan Program Energi Terbarukan Pada Sekolah Menengah Kejuruan Di Indonesia. Bandung: Pusat Pengembangan Dan Pemberdayaan Pendidik Dan Tenaga Kependidikan (PPPPTK).

Febrinanda Dhimas Prakoso (2009).Kinerja Pompa Air Portable Berdasarkan Intensitas Tenaga Surya.

Sarwoko. (2012). Uji Karakteristik Sel Surya pada Sistem 24 Volt DC sebagai Catudaya pada Sistem Pembangkit Tenaga Hybrid. Skripsi. Universitas Negeri Jakarta.

Septayudha, Arie, Warsito Agung, dan Karnoto. (2010). Perancangan Inverter Jenis Push-Pull Dan On/Off Battery Charger 